20.I2.I96I-26.II.20I 9

\title{
Adeus a Joaquim Maia de Lima
}

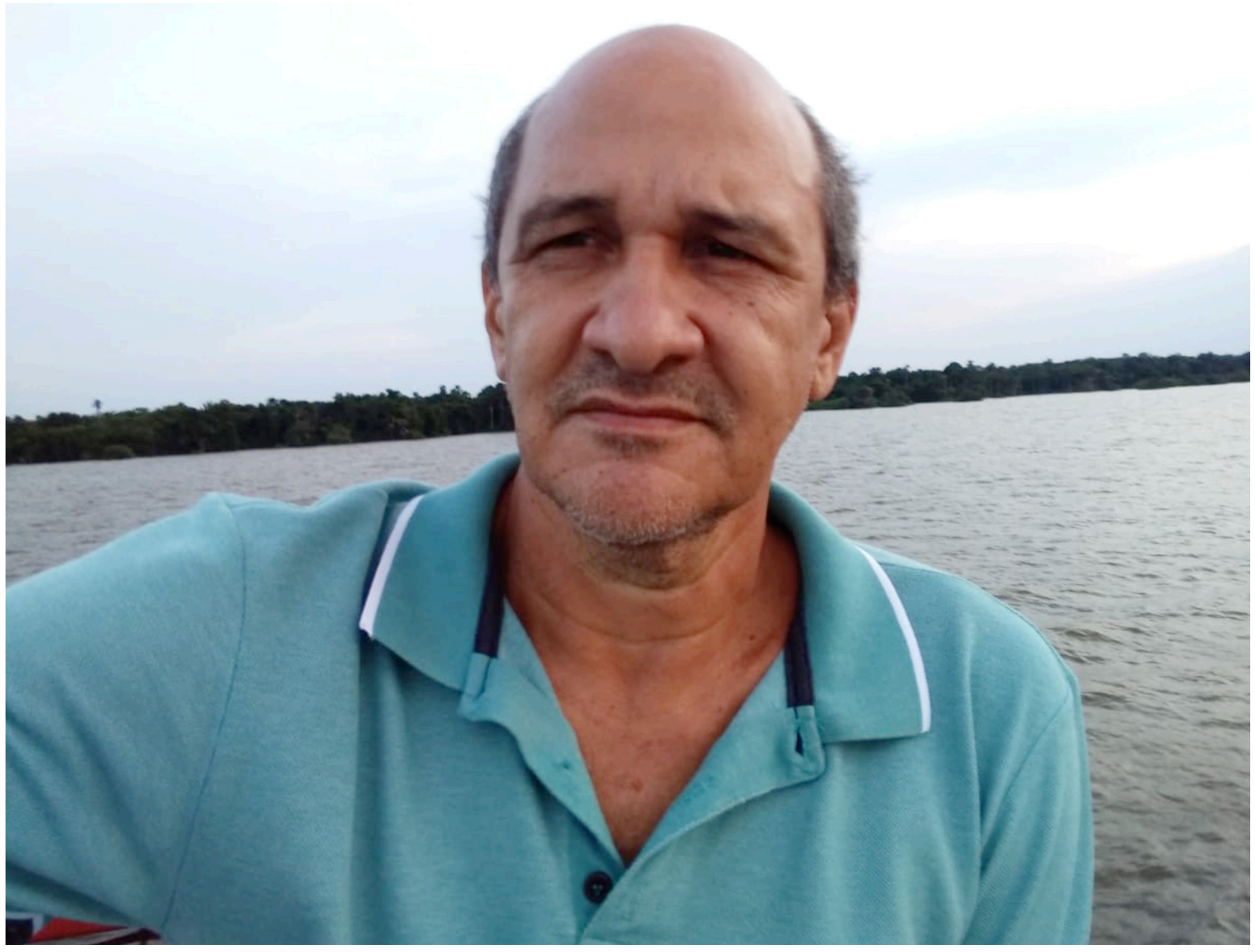

JOAQUim MAIA DE LIMA atuou no Instituto de Letras e Comunicação da Universidade Federal do Pará desde i 997. O professor obteve o título de mestre em 2002 e cursava doutorado na Universidade de Lisboa, Departamento de Educação, na área de Tecnologias da Educação. Coordenou a elaboração do projeto pedagógico do Parfor — Língua Portuguesa, curso de que foi primeiro coordenador. Nos últimos anos, dedicou-se a ministrar disciplinas ligadas ao ensino-aprendizagem na graduação e nos cursos de especialização em que atuava, inclusive como coordenador. Atuou também como professor formador e conteudista do curso de Educação a Distância em Letras. Além disso, integrou e coordenou projetos de Extensão. Foi responsável pela formação de muitos professores, na condição de professor de disciplina ou orientando Trabalhos de Conclusão de Curso (TCC); tendo marcado sua carreira a defesa de TCC de aluna que, não podendo deslocar-se à capital para defendê-lo, foi autorizada, a pedido desse professor, a realizar a defesa em sua casa. 


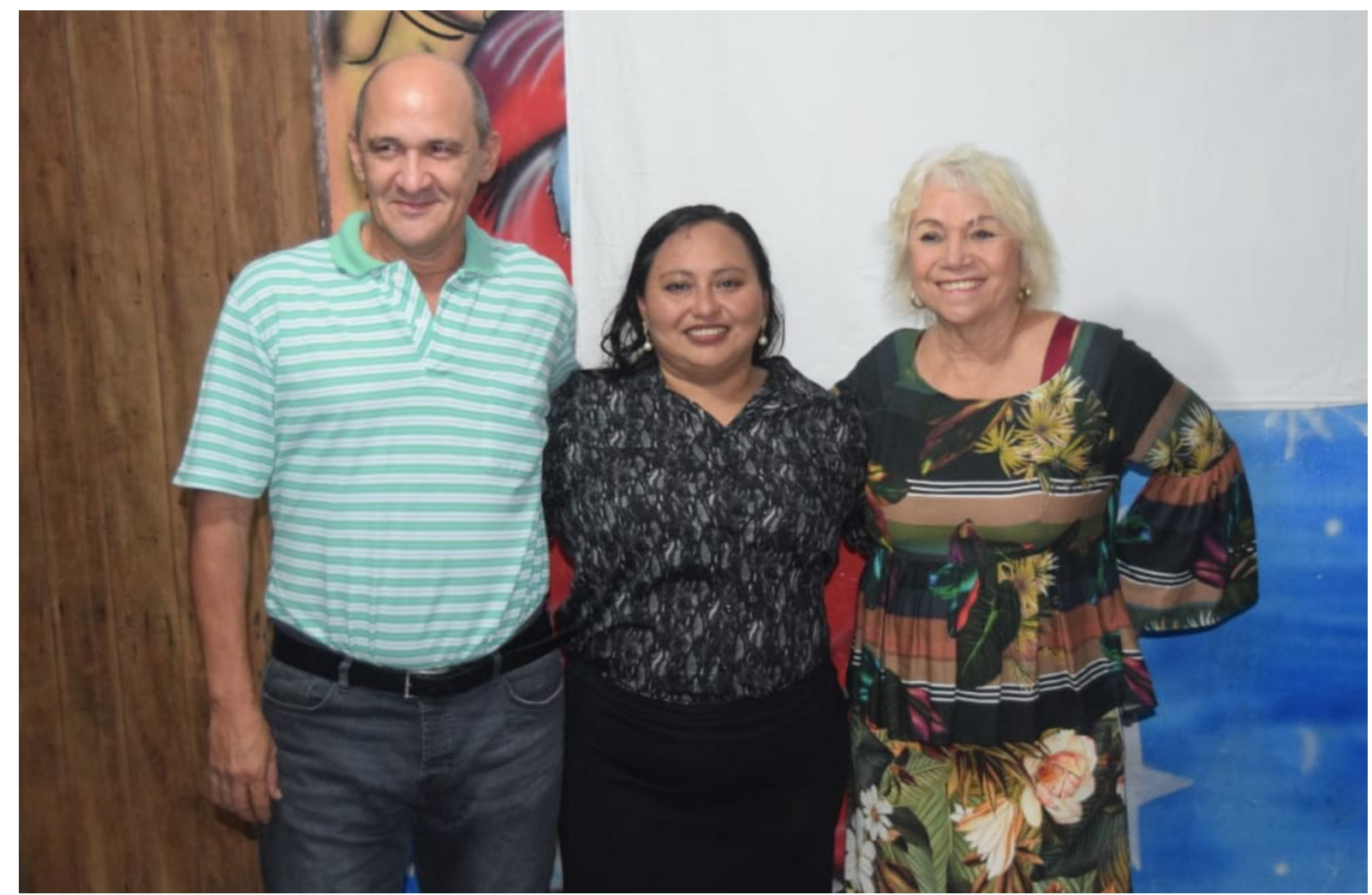

Ele e a professora Elizabete Vidal deslocaram-se até Muaná, para a realização da defesa (foto acima). Posturas como essa conduziram seu entendimento amplo, humanizado sobre o que significava formar pessoas, na teoria e na prática, tão bem registrado no texto presente na foto: "O melhor gesto do professor é abrir os braços para o acolhimento de outros seres humanos, para, juntos, sentirem a emoção da aventura humana”. Além disso,

O melhor gesto do professor é abrir os braços para acolhimento de outros seres humanos, para, juntos, sentirem a emoção da aventura humana.



era um colega indispensável e atuante na luta em defesa dos direitos humanos. Maia, como normalmente o chamávamos, tinha o CONDÃo de humanizar tudo que fazia, dizia ou pensava.

Deixa-nos uma saudade que não se pode (d)escrever.

Deixamos, aqui, nossa gratidão.

Marilucia Oliveira Elizabete Vidal Célia Zeri 